\title{
Nutrient Uptake by Sugarcane as Influenced by Different Subsoiling and Preparatory Tillage Operations
}

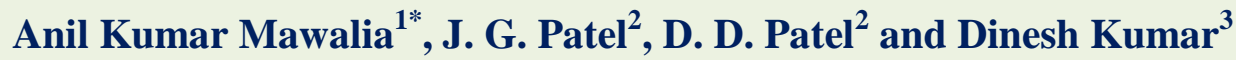 \\ ${ }^{1}$ Department of Agronomy, N.M. College of Agriculture, NAU, Navsari, \\ Gujarat-396 450, India \\ ${ }^{2}$ Department of Agronomy, College of Agriculture, Bharuch, NAU, Navsari, \\ Gujarat-392 012, India \\ ${ }^{3}$ Agronomy Section, ICAR - National Dairy Research Institute, Karnal - 132001, \\ Haryana, India \\ *Corresponding author
}

\begin{tabular}{|c|}
\hline Keywords \\
\hline $\begin{array}{l}\text { Content, Subsoiling, } \\
\text { Sugarcane, Tillage, } \\
\text { Uptake }\end{array}$ \\
\hline Article Info \\
\hline $\begin{array}{l}\text { Accepted: } \\
20 \text { May } 2018 \\
\text { Available Online: } \\
\text { 10 June } 2018\end{array}$ \\
\hline
\end{tabular}

\section{A B S T R A C T}

The experiment consisting of five subsoiling treatments $\left(\mathrm{S}_{0}\right.$ to $\left.\mathrm{S}_{4}\right)$ viz., no subsoiling $\left(\mathrm{S}_{0}\right)$, subsoiling at $1.5 \mathrm{~m}$ distance $\left(\mathrm{S}_{1}\right)$, subsoiling at $2.0 \mathrm{~m}$ distance $\left(\mathrm{S}_{2}\right)$, cross subsoiling at 1.5 $\mathrm{m} \times 1.5 \mathrm{~m}\left(\mathrm{~S}_{3}\right)$ and cross subsoiling at $2.0 \mathrm{~m} \times 2.0 \mathrm{~m}\left(\mathrm{~S}_{4}\right)$ and two preparatory tillage practices, i.e., 2 and 4 harrowing was laid in split plot design with four replications. Various subsoiling practices did not show any significant effect on nitrogen, phosphorus and potassium content (\%) in sugarcane leaf blade, leaf sheath and stalk at harvest during both the years of experimentation and pooled result. Variations in nitrogen, phosphorus and potassium uptake in canes were significant due to various subsoiling practices in both the years and combined analysis. The crop grown with cross subsoiling at $1.5 \mathrm{~m}$ distance removed significantly more nitrogen $\left(244.0,246.2\right.$ and $245.1 \mathrm{~kg} \mathrm{ha}^{-1}$, respectively), phosphorus (116.8, 116.1 and $116.4 \mathrm{~kg} \mathrm{ha}^{-1}$, respectively) and potassium $(388.1,390.3$ and $389.2 \mathrm{~kg} \mathrm{ha}^{-1}$, respectively) than remaining treatments but at par with cross subsoiling at $2.0 \mathrm{~m}$ distance and subsoiling at $1.5 \mathrm{~m}$ distance in both the years (2016 and 2017) and in combined analysis, respectively. The differences in nitrogen, phosphorus and potassium content $(\%)$ and uptake by canes due to different preparatory tillage operations were nonsignificant. However, the maximum nitrogen, phosphorus and potassium removal by canes was with four harrowing, whereas the minimum with two harrowing in first year, second year and pooled analysis.

\section{Introduction}

Sugarcane is an important agro-industrial crop of India. It is a warmth and bright weather loving crop and can tolerate intermittent soil drough in vegetative phase and requires a mild soil drought during its maturity perios. It is therefore, a crop of tropics and sub-tropics. In india, it occupies 5.06 million ha area, i.e., around 3 per cent of the total cultivated area with the production and productivity of 361.04 million tonnes and $71.6 \mathrm{t} \mathrm{ha}^{-1}$ in Inida, respectively (Anon., 2015). It is mostly grown in Uttar Pradesh, Tamil Nadu, Maharastra, 
Karnataka, Gujarat, Andhra Pradesh etc. In Gujarat, it is cultivated as cash crop. Heavy rainfall, perennial canal irrigation facility and good infrastructure of sugar factories enhanced the sugarcane cultivation in south Gujarat. The soil cultivation operations changed over the years according to sources of farm power. During 1960s, the soil cultivation was limited to $100-120 \mathrm{~mm}$ depth with the help of animate power sources. Although tractors up to $80 \mathrm{hp}$ are available in the country, the soil cultivation has not changed much and confined to shallow depths of 100$150 \mathrm{~mm}$ with the help of cultivators, harrows etc. which is almost similar to a country plough. However, a few farmers also option for deep tillage up to $200 \mathrm{~mm}$ depth occasionally with mould board or disc ploughs. In Indian subsoil (>250 mm depth) has not been tilled in the past due to lack of high tractor power. The recent years, however, have witnessed a definite shift towards high hp tractors.

Soil compaction is emerging as a serious problem affecting the yield of field crops leading to soil degradation worldwide. Compaction-induced soil degradation affects about 68 million hectares and 11 per cent of land globally (Flowers and Lal, 1998). Soil compaction is the compression of soil by external forces that decrease the volume of pore space while increasing the soil density (Harris, 1971). A thick compacted layer builds up in the root zone as a consequence of poor tillage practices, primarily as a result of the farmer failing to vary the depth of ploughing over several years (Tursic et al., 2008). The effect of compaction includes reduced soil aeration, infiltration of rainfall, poor soil structure, increased soil strength and resistance to root penetration (Mac and Bristow, 2001). Soil compaction below tillage depths $(>20-25 \mathrm{~cm})$ is of greater concern than the surface compaction because it is a difficult problem to solve (Thakur, 2012).
For obtaining these targets, development of improved technologies holds the key. However, soil management technologies especially subsoil has not received much attention. But, nowadays, mechanization in sugarcane farming is becoming more important due to the ever-increasing demand for sugarcane together with the problem of a labour shortage. Along with preparatory tillage practices also increase crop yield. Chisel ploughing and subsoiling have resulted a significant yield increase in sugarcane crop (Torres et al., 1990).

Subsoiling is a process by which the hard pan layer or compacted layer of the soil is broken without turning over the infertile subsoil to the top. This process is usually done with a tractor drawn subsoiler to a depth of at least $50 \mathrm{~cm}$.

\section{Materials and Methods}

The present experiment was laid out at College Farm, N. M. College of Agriculture, Navsari Agricultural University, Navsari during 2015-16 and 2016-17. The experimental site is geographically located at $20^{\circ} 57^{\prime} \mathrm{N}$ latitude and $72^{\circ} 54^{\prime} \mathrm{E}$ longitude at an altitude of 10 meters above the mean sea level. The soil of the experimental site was clayey in texture with slightly alkaline in reaction (8.01). The status of soil for available nitrogen (269.85 $\left.\mathrm{kg} \mathrm{ha}^{-1}\right)$, phosphorus (27.7 $\mathrm{kg} \mathrm{ha}^{-1}$ ) and potassium $\left(372.65 \mathrm{~kg} \mathrm{ha}^{-1}\right)$ was medium, medium and fairly rich. The annual average rainfall received during 2015-16 and 2016-17 were 1474.0 and $1358.6 \mathrm{~mm}$, respectively. The maximum rainfall recorded during the experimental period was 290.0 and $330.0 \mathrm{~mm}$ in $38^{\text {th }}$ week and $29^{\text {th }}$ week, respectively. The annual minimum and maximum temperature ranged from 10.4 to $38.0^{\circ} \mathrm{C}$ and 9.7 to $39.9^{\circ} \mathrm{C}$ during 2015-16 and 2016-17, respectively. The annual mean relative humidity ranged from 18.8 to 103.7 and 21.3 to 98.6 per cent during the investigation period. The mean 
sunshine hours ranged between 0.4 to 10.5 and 0.1 to 10.6 hours during the period of experimentation, respectively.

Sugarcane (var. CoN 05071) was planted on December 02, 2015 and December 10, 2016 using 50,000 two eye budded setts ha ${ }^{-1}$ seed for the experiments conducted in split plot design with four replications.

The treatments comprised different combinations of five subsoiling treatments $\left(\mathrm{S}_{0}\right.$ to $S_{4}$ ), namely no subsoiling $\left(S_{0}\right)$, subsoiling at $1.5 \mathrm{~m}$ distance $\left(\mathrm{S}_{1}\right)$, subsoiling at $2.0 \mathrm{~m}$ distance $\left(\mathrm{S}_{2}\right)$, cross subsoiling at $1.5 \mathrm{~m} \mathrm{x} 1.5 \mathrm{~m}$ $\left(\mathrm{S}_{3}\right)$ and cross subsoiling at $2.0 \mathrm{~m} \times 2.0 \mathrm{~m}\left(\mathrm{~S}_{4}\right)$ and two preparatory tillage practices, i.e., 2 harrowing and 4 harrowing. After implementing the subsoiling treatments, sugarcane was planted in furrows at $100 \mathrm{~cm}$ spacing between rows.

A recommended dose of $125 \mathrm{~kg} \mathrm{ha}^{-1}$ of $\mathrm{P}_{2} \mathrm{O}_{5}$ and $\mathrm{K}_{2} \mathrm{O}$ each in the form of single super phosphate and muriate of potash, respectively, were applied uniformly to all the experimental plots prior to planting and it was mixed with the soil. Nitrogen was applied @ $250 \mathrm{~kg} \mathrm{ha}^{-1}$ in the form of urea in all treatments in four splits, i.e., 15 per cent at the time of planting, 30 per cent at 45 days after planting, 20 per cent at 90 days after planting and 35 per cent before final earthing-up, i.e., 150 days after planting. The sugarcane samples (leaf blade, leaf sheath and stalk) collected at harvest were oven dried and ground to 40 mesh and utilized for estimation of nitrogen, phosphorus and potassium content. Plant samples were digested in di-acid mixture. The extract prepared after digestion was used for estimation of $\mathrm{N}, \mathrm{P}_{2} \mathrm{O}_{5}$ and $\mathrm{K}_{2} \mathrm{O}$ content as per the following methods:

Nitrogen- The nitrogen was estimated by modified micro Kjeldahl's method (Jackson, 1967).
Phosphorus- Unreduced vanadomolybdate phosphoric acid yellow colour method was used for estimation of phosphorus from the extract (Jackson, 1967).

Potassium- The potassium from the extract was determined by Flame photometer (Jackson, 1967).

The uptake of nutrients was calculated by multiplying the dry matter yield with the respective percentage of compositions of different nutrients. The total uptake for $\mathrm{N}$, $\mathrm{P}_{2} \mathrm{O}_{5}$ and $\mathrm{K}_{2} \mathrm{O}$ by the sugarcane crop was obtained by summing the uptake of respective nutrients by leaf blade, leaf sheath and stalk.

\section{Results and Discussion}

\section{NPK content (\%) in sugarcane leaf blade, leaf sheath and stalk at harvest}

The mean data with respect to nutrient content (\%) in sugarcane leaf blade, leaf sheath and stalk at harvest as influenced by different treatments are presented in Table 1,2 and 3.

The data (Table 1, 2 and 3) showed that various subsoiling practices did not show any significant effect on nitrogen, phosphorus and potassium content (\%) in sugarcane leaf blade, leaf sheath and stalk at harvest during both the years of experimentation and pooled result.

However, maximum nitrogen, phosphorus and potassium content (\%) was observed in cross subsoiling at $1.5 \mathrm{~m}$ distance then that of other subsoiling treatments.

The data pertaining to nitrogen, phosphorus and potassium content (\%) in sugarcane (Table 1, 2 and 3), indicated that different preparatory tillage practices did not manifest their significant influence on nitrogen, phosphorus and potassium content (\%) in leaf blade, leaf sheath and stalk at harvest. 
Table.1 Effect of subsoiling and preparatory tillage operation on nutrient content (\%) of sugarcane leaf blade at harvest

\begin{tabular}{|c|c|c|c|c|c|c|c|c|c|}
\hline \multirow[t]{2}{*}{ Treatments } & \multicolumn{3}{|c|}{$\mathbf{N}$ content $(\%)$} & \multicolumn{3}{|c|}{$P$ content $(\%)$} & \multicolumn{3}{|c|}{$\mathrm{K}$ content $(\%)$} \\
\hline & 2015-16 & 2016-17 & Pooled & 2015-16 & 2016-17 & Pooled & 2015-16 & 2016-17 & Pooled \\
\hline \multicolumn{10}{|l|}{ Subsoiling (S) } \\
\hline S-0: No subsoiling & 0.700 & 0.706 & 0.703 & 0.263 & 0.267 & 0.265 & 0.962 & 0.970 & 0.966 \\
\hline S-1: SS at $1.5 \mathrm{~m}$ distance & 0.726 & 0.733 & 0.729 & 0.271 & 0.274 & 0.272 & 0.983 & 1.005 & 0.994 \\
\hline S-2: SS at $2.0 \mathrm{~m}$ distance & 0.712 & 0.724 & 0.718 & 0.267 & 0.270 & 0.269 & 0.973 & 0.992 & 0.982 \\
\hline S-3: CSS at $1.5 \mathrm{~m}$ distance & 0.742 & 0.745 & 0.743 & 0.284 & 0.284 & 0.284 & 1.027 & 1.033 & 1.030 \\
\hline S-4: CSS at $2.0 \mathrm{~m}$ distance & 0.732 & 0.742 & 0.737 & 0.278 & 0.280 & 0.279 & 0.998 & 1.015 & 1.006 \\
\hline SEm \pm & 0.009 & 0.009 & 0.009 & 0.005 & 0.004 & 0.004 & 0.014 & 0.013 & 0.014 \\
\hline $\mathrm{CD}(\mathrm{P}=0.05)$ & NS & NS & NS & NS & NS & NS & NS & NS & NS \\
\hline C.V. \% & 3.57 & 3.38 & 3.47 & 4.95 & 4.42 & 4.56 & 4.04 & 3.75 & 3.89 \\
\hline \multicolumn{10}{|l|}{ Preparatory tillage (H) } \\
\hline H-1: 2 harrowing & 0.720 & 0.728 & 0.724 & 0.276 & 0.273 & 0.274 & 0.983 & 0.998 & 0.990 \\
\hline H-1: 4 harrowing & 0.725 & 0.731 & 0.728 & 0.269 & 0.277 & 0.273 & 0.994 & 1.008 & 1.001 \\
\hline SEm \pm & 0.006 & 0.005 & 0.005 & 0.003 & 0.002 & 0.003 & 0.008 & 0.008 & 0.008 \\
\hline $\mathrm{CD}(\mathrm{P}=0.05)$ & NS & NS & NS & NS & NS & NS & NS & NS & NS \\
\hline C.V. \% & 3.41 & 3.11 & 3.24 & 5.41 & 3.22 & 4.19 & 3.72 & 3.38 & 3.54 \\
\hline \multicolumn{10}{|l|}{ Interaction (S x H) } \\
\hline SEm \pm & 0.012 & 0.011 & 0.012 & 0.007 & 0.004 & 0.006 & 0.018 & 0.017 & 0.018 \\
\hline $\mathrm{CD}(\mathrm{P}=0.05)$ & NS & NS & NS & NS & NS & NS & NS & NS & NS \\
\hline
\end{tabular}

\#Interaction effect of year with all factors found non-significant 
Table.2 Effect of subsoiling and preparatory tillage operation on nutrient content (\%) of sugarcane leaf sheath at harvest

\begin{tabular}{|c|c|c|c|c|c|c|c|c|c|}
\hline \multirow{2}{*}{ Treatments } & \multicolumn{3}{|c|}{$\mathbf{N}$ content $(\%)$} & \multicolumn{3}{|c|}{ P content $(\%)$} & \multicolumn{3}{|c|}{ K content $(\%)$} \\
\hline & 2015-16 & 2016-17 & Pooled & 2015-16 & 2016-17 & Pooled & 2015-16 & 2016-17 & Pooled \\
\hline \multicolumn{10}{|l|}{ Subsoiling (S) } \\
\hline S-0: No subsoiling & 0.378 & 0.387 & 0.383 & 0.180 & 0.179 & 0.180 & 0.905 & 0.896 & 0.900 \\
\hline S-1: SS at $1.5 \mathrm{~m}$ distance & 0.388 & 0.393 & 0.390 & 0.188 & 0.189 & 0.189 & 0.917 & 0.919 & 0.918 \\
\hline S-2: SS at $2.0 \mathrm{~m}$ distance & 0.382 & 0.390 & 0.386 & 0.185 & 0.185 & 0.185 & 0.911 & 0.906 & 0.909 \\
\hline S-3: CSS at $1.5 \mathrm{~m}$ distance & 0.408 & 0.406 & 0.407 & 0.199 & 0.202 & 0.200 & 0.952 & 0.948 & 0.950 \\
\hline S-4: CSS at $2.0 \mathrm{~m}$ distance & 0.398 & 0.400 & 0.399 & 0.192 & 0.195 & 0.194 & 0.930 & 0.938 & 0.934 \\
\hline SEm \pm & 0.007 & 0.005 & 0.006 & 0.004 & 0.005 & 0.004 & 0.011 & 0.012 & 0.011 \\
\hline $\mathrm{CD}(\mathrm{P}=\mathbf{0 . 0 5})$ & NS & NS & NS & NS & NS & NS & NS & NS & NS \\
\hline C.V. \% & 4.97 & 3.65 & 4.26 & 6.06 & 7.43 & 6.63 & 3.23 & 3.82 & 3.52 \\
\hline \multicolumn{10}{|l|}{ Preparatory tillage (H) } \\
\hline H-1: 2 harrowing & 0.389 & 0.393 & 0.391 & 0.187 & 0.188 & 0.188 & 0.917 & 0.918 & 0.918 \\
\hline H-1: 4 harrowing & 0.393 & 0.398 & 0.395 & 0.191 & 0.192 & 0.192 & 0.929 & 0.924 & 0.927 \\
\hline SEm \pm & 0.003 & 0.003 & 0.003 & 0.002 & 0.002 & 0.002 & 0.006 & 0.007 & 0.006 \\
\hline $\mathrm{CD}(\mathrm{P}=0.05)$ & NS & NS & NS & NS & NS & NS & NS & NS & NS \\
\hline C.V. $\%$ & 3.48 & 3.06 & 3.22 & 3.76 & 3.62 & 3.57 & 2.68 & 3.38 & 3.02 \\
\hline \multicolumn{10}{|l|}{ Interaction (S x H) } \\
\hline SEm \pm & 0.007 & 0.006 & 0.006 & 0.004 & 0.003 & 0.003 & 0.012 & 0.016 & 0.014 \\
\hline $\mathrm{CD}(\mathrm{P}=0.05)$ & NS & NS & NS & NS & NS & NS & NS & NS & NS \\
\hline
\end{tabular}

\#Interaction effect of year with all factors found non-significant 
Table.3 Effect of subsoiling and preparatory tillage operation on nutrient content (\%) of sugarcane stalk at harvest

\begin{tabular}{|c|c|c|c|c|c|c|c|c|c|}
\hline \multirow[t]{2}{*}{ Treatments } & \multicolumn{3}{|c|}{$\mathbf{N}$ content $(\%)$} & \multicolumn{3}{|c|}{$P$ content $(\%)$} & \multicolumn{3}{|c|}{$\mathrm{K}$ content $(\%)$} \\
\hline & 2015-16 & 2016-17 & Pooled & 2015-16 & 2016-17 & Pooled & 2015-16 & 2016-17 & Pooled \\
\hline \multicolumn{10}{|l|}{ Subsoiling (S) } \\
\hline S-0: No subsoiling & 0.271 & 0.279 & 0.275 & 0.194 & 0.188 & 0.191 & 0.290 & 0.298 & 0.294 \\
\hline S-1: SS at $1.5 \mathrm{~m}$ distance & 0.277 & 0.287 & 0.282 & 0.199 & 0.194 & 0.197 & 0.299 & 0.305 & 0.302 \\
\hline S-4: CSS at $2.0 \mathrm{~m}$ distance & 0.285 & 0.291 & 0.288 & 0.202 & 0.195 & 0.199 & 0.307 & 0.310 & 0.308 \\
\hline SEm \pm & 0.005 & 0.004 & 0.004 & 0.003 & 0.002 & 0.003 & 0.005 & 0.005 & 0.005 \\
\hline $\mathrm{CD}(\mathrm{P}=\mathbf{0 . 0 5})$ & NS & NS & NS & NS & NS & NS & NS & NS & NS \\
\hline C.V. \% & 4.60 & 4.16 & 4.28 & 4.66 & 3.54 & 3.85 & 4.94 & 4.29 & 4.44 \\
\hline \multicolumn{10}{|l|}{ Preparatory tillage (H) } \\
\hline H-1: 4 harrowing & 0.282 & 0.290 & 0.286 & 0.200 & 0.194 & 0.197 & 0.302 & 0.308 & 0.305 \\
\hline SEm \pm & 0.002 & 0.002 & 0.002 & 0.001 & 0.002 & 0.001 & 0.001 & 0.002 & 0.002 \\
\hline $\mathrm{CD}(\mathrm{P}=\mathbf{0 . 0 5})$ & NS & NS & NS & NS & NS & NS & NS & NS & NS \\
\hline C.V. $\%$ & 3.09 & 3.08 & 3.01 & 2.30 & 3.69 & 2.84 & 2.13 & 2.87 & 2.39 \\
\hline \multicolumn{10}{|l|}{ Interaction (S x H) } \\
\hline SEm \pm & 0.004 & 0.004 & 0.004 & 0.002 & 0.004 & 0.003 & 0.003 & 0.004 & 0.004 \\
\hline $\mathrm{CD}(\mathrm{P}=0.05)$ & NS & NS & NS & NS & NS & NS & NS & NS & NS \\
\hline
\end{tabular}

\#Interaction effect of year with all factors found non-significant 
Table.4 Effect of subsoiling and preparatory tillage operation on total nutrient uptake $\left(\mathrm{kg} \mathrm{ha}^{-1}\right)$ of sugarcane plant at harvest

\begin{tabular}{|c|c|c|c|c|c|c|c|c|c|}
\hline \multirow[t]{2}{*}{ Treatments } & \multicolumn{3}{|c|}{ N uptake } & \multicolumn{3}{|c|}{ P uptake } & \multicolumn{3}{|c|}{ K uptake } \\
\hline & 2015-16 & 2016-17 & Pooled & 2015-16 & 2016-17 & Pooled & 2015-16 & 2016-17 & Pooled \\
\hline \multicolumn{10}{|l|}{ Subsoiling (S) } \\
\hline S-0: No subsoiling & 187.9 & 191.3 & 189.6 & 88.7 & 88.6 & 88.7 & 300.2 & 301.9 & 301.0 \\
\hline S-1: SS at $1.5 \mathrm{~m}$ distance & 222.0 & 223.8 & 222.9 & 105.1 & 104.1 & 104.6 & 351.0 & 353.4 & 352.2 \\
\hline S-4: CSS at $2.0 \mathrm{~m}$ distance & 229.1 & 233.4 & 231.3 & 108.9 & 109.2 & 109.0 & 361.8 & 368.3 & 365.0 \\
\hline SEm \pm & 10.62 & 10.02 & 10.31 & 5.38 & 5.10 & 5.23 & 16.5 & 16.1 & 16.3 \\
\hline $\mathrm{CD}(\mathrm{P}=0.05)$ & 32.7 & 30.9 & 31.8 & 16.6 & 15.7 & 16.1 & 50.9 & 49.7 & 50.3 \\
\hline C.V. \% & 13.7 & 12.8 & 13.2 & 14.6 & 14.0 & 14.3 & 13.5 & 13.0 & 13.2 \\
\hline H-1: 4 harrowing & 225.4 & 228.5 & 227.0 & 106.4 & 107.0 & 106.7 & 358.3 & 361.0 & 359.6 \\
\hline SEm \pm & 5.47 & 5.39 & 5.42 & 2.70 & 2.57 & 2.63 & 8.50 & 8.71 & 8.59 \\
\hline $\mathrm{CD}(\mathrm{P}=0.05)$ & NS & NS & NS & NS & NS & NS & NS & NS & NS \\
\hline C.V. $\%$ & 11.2 & 10.9 & 11.0 & 11.6 & 11.1 & 11.3 & 11.0 & 11.1 & 11.0 \\
\hline \multicolumn{10}{|l|}{ Interaction (S x H) } \\
\hline SEm \pm & 12.2 & 12.05 & 12.13 & 6.04 & 5.76 & 5.88 & 19.0 & 19.5 & 19.2 \\
\hline $\mathrm{CD}(\mathrm{P}=0.05)$ & NS & NS & NS & NS & NS & NS & NS & NS & $\mathrm{NS}$ \\
\hline
\end{tabular}

\#Interaction effect of year with all factors found non-significant 
However, nitrogen, phosphorus and potassium content (\%) higher with four harrowing followed by two harrowing.

Interaction between subsoiling and preparatory tillage operation did not show any significant effect with respect to nitrogen, phosphorus and potassium content (\%) in leaf blade, leaf sheath and stalk at harvest during both the years of study as well as combined analysis.

\section{Total NPK uptake $\left(\mathrm{kg} \mathrm{ha}^{-1}\right)$ by sugarcane crop at harvest}

The total nitrogen, phosphorus and potassium uptake $\left(\mathrm{kg} \mathrm{ha}^{-1}\right)$ by sugarcane crop at harvest are presented in Table 4. Variations in nitrogen, phosphorus and potassium uptake in canes were significant due to various subsoiling practices in both the years and combined analysis. The crop grown with cross subsoiling at $1.5 \mathrm{~m}$ distance removed significantly more nitrogen, phosphorus and potassium than remaining treatments but at par with cross subsoiling at $2.0 \mathrm{~m}$ distance and subsoiling at $1.5 \mathrm{~m}$ distance in both the years and in combined analysis, respectively.

Crop grown under cross subsoiling at $1.5 \mathrm{~m}$ distance treatment removed significantly more nitrogen (244.0, 246.2 and $245.1 \mathrm{~kg} \mathrm{ha}$ $\left.{ }^{1}\right)$, phosphorus $\left(116.8,116.1\right.$ and $116.4 \mathrm{~kg} \mathrm{ha}^{-}$ $\left.{ }^{1}\right)$ and potassium $(388.1,390.3$ and $\mathrm{x} 389.2 \mathrm{~kg}$ $\mathrm{ha}^{-1}$ ) from soil than that of the remaining treatments during first year, second year and combined analysis. The removal of nutrient is a function of its content multiplied by the dry matter yield, thus higher uptake can be credited largely to enhanced yield due to subsoiling operations. Nutrient uptake significantly influenced by subsoiling practices during both the years. Almost similar findings were also reported by Ishaq et al., 2001, Kumar, 2003 and Singh et al., (2016).
The differences in nitrogen, phosphorus and potassium uptake by canes due to different preparatory tillage operations were nonsignificant. However, the maximum nitrogen, phosphorus and potassium removal by canes was with four harrowing, whereas the minimum with two harrowing in first year, second year and pooled analysis.

The chemical properties of soil and nutrient content and uptake by sugarcane crop was non-significantly affected by preparatory tillage practices in both the years as well as in pooled analysis. The result could be supported by studies of Nitant et al., (1995).

The interaction between subsoiling and preparatory tillage treatments with respect to nitrogen, phosphorus and potassium uptake by canes was not significant in canes in both the years and combined analysis.

\section{References}

Anonymous. 2015. India Stat.com

Flowers, M.D. and Lal, R. 1998. Axle load and tillage effects on soil physical properties and soybean grain yield on a mollicochraqualf in northwest Ohio. Soil and Tillage Research, 48: 21-35.

Harris, W.L. 1971. The soil compaction process. In: Compaction of Agricultural Soils, edited by Barnes KK et al., American Society Agricultural Engineers, St. Joseph, MI 9-44.

Ishaq, M., Ibrahim, M., Hassan, A., Saeed, M. and Lal, R. 2001. Subsoil effects on crops in Punjab, Pakistan-II. Root growth and nutrient uptake of wheat and sorghum. Soil and Tillage Research, 60: 153-161.

Jackson, M.L. 1967. "Soil Chemical Analysis" Prentice Hall of India. Pvt. Ltd., New Delhi, pp. 183-192.

Kumar A. 2003. Design and development of winged subsoiler with leading tines and 
maize crop response to subsoiling. Ph.D. Thesis, G. B. Pant University of Agriculture and Technology, Pantnagar. pp 1-167.

Mac, G.D. and Bristow, K.L. 2001. Sugarcane production and soil physical decline. Proceedings of the ISSCT, 24: 3-7.

Nitant, H.C., Singh P. and Singh, P. 1995. Effects of deep tillage on dry land production of redgram (Cajanus cajan L.) in central India. Soil and Tillage Research, 34(1): 17-26.

Singh, P., Saini, S.K., Thakur, T.C. and Bkatnagar A. 2016. Subsoiling and fertilizer placement effect on yield performence, soil physico- chemical properties, nutrients uptake and utrient recovery by sugarcane. International Journal of Basic and Applied Agriculture Research, 14(3): 261-266.
Thakur, T.C. 2012. Subsoil structure modification and its fortification-A necessity for introduction of sugarcane harvesters in Northern India. All India Seminar on Mechanization of Sugarcane Harvesting Opportunities and Challenges held at Indian Institute of Sugarcane Research (ICAR), Lukhnow during $27^{\text {th }}$ April, pp28-38.

Torres, J.S., Yang, S.J. and Villegas, F. 1990. Soil compaction and cane stalk damage by semi-mechanized harvesting systems in the wet season. Sugar Cane, 5: 12-16.

Tursic, I., Husnjak, S. and Zalac, Z. 2008. Soil compaction as one of the causes of lower tobacco yields in the republic of Croatia. Cereal Research Communications, 36: 687-690.

\section{How to cite this article:}

Anil Kumar Mawalia, J. G. Patel, D. D. Patel and Dinesh Kumar. 2018. Nutrient Uptake by Sugarcane as Influenced by Different Subsoiling and Preparatory Tillage Operations. Int.J.Curr.Microbiol.App.Sci. 7(06): 2939-2947. doi: https://doi.org/10.20546/ijcmas.2018.706.346 